Ambient Science, 2018: Vol. 05(Sp2); 01-04

DOI:10.21276/ambi.2018.05.sp2.ga01

\title{
Toxic Waste, Health Issues and Waste Management: an Overview
}

\author{
Renu Maheshwari*, Kavita Das, Shashi Gupta \\ Department of Zoology, Govt. N.P.G. College of Science, Raipur, \\ Chhattisgarh, India
}

Key words: Pollution, Landfill, Domestic Wastes, Industrial Wastes, Hazardous.

\section{Introduction:}

One of the reasons for environmental pollution is toxic waste. These wastes may in the form of any hazardous solid, liquid or gas. Improper treatment and absences of awareness to properly plan for waste management would become the factor for serious and severe damages to human health (Alam, 2013; Dhote, 2016).

World Bank has well documented about the facts and figures which shows that the production of urban waste increased faster than the rate of urbanization and the production of waste would be increased more than three times by 2025 (https://www.ecozgreetings.com/News/worldswasteful-countries.html).

Waste composition is diverse. It may be biological, chemical, electronic and nuclear. In India municipal solid wastes (MSW) are classified under domestic hazardous waste (household hazardous waste), biodegradable waste includes kitchen and garden wastes, whereas the composite wastes include plastic, recyclable waste like paper, metals, glass \& some types of plastics and toxic wastes which are e-waste, medical waste, and chemical waste. The toxic level also increased due to organic wastes (Daniel et al., 2018), electrical goods (bulbs, batteries), fertilizers and pesticides (Joshi \& Ahmed, 2016) etc.

As per Namen et al., (2014) the impact of waste depends upon the composition of the waste and illegal practices for their dispose off. Deterioration of land, water bodies including underground water and the air is due to illegal/improper dumping of waste (Triassi et al., 2015) that exert many harmful effects on the environment and human health and more pronounced to them who worked for waste management (Singh, 2013). Several studies revealed health issues directly related to waste and waste management (Martuzzi et al., 2009; Giusti, 2009; Musmeci et al., 2010; Gouveia \& Prado, 2010; Fazzo et al.,

\section{Abstract}

Waste composition is diverse. It may be biological, chemical, electronic and nuclear. Generally waste may be any hazardous solid, liquid or gas. Unscientifically dispose of waste is accountable for environmental pollution and human health issues. There are so many methods for waste management such as landfill, combustion, recycling, recovery, reducing and composting. By keeping in view the present scenario, the aim for the present article is to create awareness towards the health issues due to the toxic waste.

2011; Singh, 2013). Further, improper management of hospital solid waste also becoming a major threats for human health (Dehghani \& Vafadar, 2017).

For waste management, there are so many methods are under operation, such as landfill, combustion, recycling, recovery, reducing and composting (Rushton, 2003, Danthurebandara et al., 2015; Joshi \& Ahmed, 2016; Moya et al., 2017; Bourn et al., 2018; Rama Murthy et al., 2018; and Adelopo et al., 2018). Combustion, recycling, recovery, reducing and composting are the methods by which MSW gets converted into usable kinds of stuff and finally reduces the stress on the landf ill.

\section{Landfill management:}

Landfill is dumping site on land where the garbage or hazardous wastes are dumped. In India, it is very common practice to discard MSW near roadside which is always harmful to the society. The poorly managed landfill has many adverse effects on the environment and human health (Fig.-1).

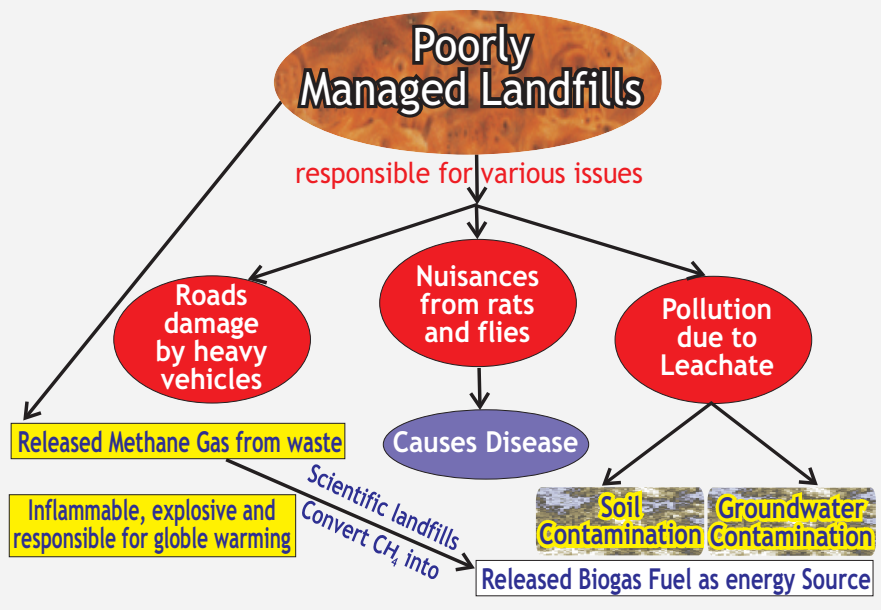

Figure-1: Plan for poorly managed landfill 
Short-term and long-term effect on health due to landfill: Mattiello et al. (2013) and Porta et al. (2009) were documented that environment is polluted due to waste dumping which reveals some short-term as well as longterm health effects. Short-term health effects include respiratory infection, asthma, congenital anomalies (Ashworth et al., 2014; Elliott et al., 2001) and headache, stress, anxiety, dizziness, nausea, eye \& respiratory irritation (Kah et al., 2012). Nevertheless, the long-term health effects like chronic respiratory disorder, cardiovascular disorder, CNS disorder, cancer, diseases related with liver and kidney were reported by Carpenter et al. (2008); Minichilli et al. (2005) and Vrijheid (2000).

Health hazards due to gaseous issues from landfill: unscientifically landfill pollute the environment by releasing harmful gases like $\mathrm{CO}_{2}, \mathrm{CH}_{4}, \mathrm{H}_{2} \mathrm{~S}$, metal vapours, and VOCs which creates many adverse effects on human health like cancer; neoplasm of lung, liver, bladder, larynx, colorectal, soft tissues sarcoma, kidney and gastric cancer including birth defects, childhood mortality and respiratory problems (Triassi et al., 2015; Benedetti et al., 2015; Mattiello et al., 2013; Porta et al., 2009; Russi et al., 2008 and WHO, 2007). As per De Felice et al. (2012) and Guida et al. (2010) the person who lives nearby landf ill site are much prone to health problems.

Health issues due to leachate: liquid drain from the landf ill is termed leachate which comes out with rainwater and moisture of waste in the landfill. It contains inorganic and organic pollutants which are toxic to the environment and affects the ambient faunal community (Lavrova \& Koumanova, 2010). As per Nagrajan et al. (2012) the leachate percolates and contaminates the water bodies including domestic water supply near the landfill site by heavy metals $(\mathrm{Zn}, \mathrm{Pb}, \mathrm{Cu}, \mathrm{Fe}, \mathrm{Cr}, \mathrm{Cd}, \mathrm{Ni})$ and high concentration of $\mathrm{NH}_{4}^{+}, \mathrm{NO}_{3}^{-}, \mathrm{Cl}-, \mathrm{SO}_{4}{ }^{-}$that have significant threat for the society. El-Salam \& Abu-Zuid (2015) revealed that toxic nature of leachate does not contaminate much the groundwater but disturbs the standard of some of the parameters like TDS, water conductivity, iron, sulphates, chlorides, and manganese as compared to WHO \& EPA standards. Naveen et al. (2016) carried out various studies on leachate and water quality of water bodies existing nearby landfill sites which were found to be unhealthy for domestic purposes. Report on health issues due to leachate was also given by Danthurebandara et al. (2012).

Threats for global warming due to landfill: main cause for the global warming is an emission of greenhouse gases (Patz et al., 2007; Myers, 2009; Powell et al., 2016) and some of the responsive greenhouse gases are $\mathrm{CO}_{2}, \mathrm{~N}_{2} \mathrm{O}$, and $\mathrm{CH}_{4}$. As methane and carbon dioxide are mainly released from landfill, thus the landfill could also be a source for alteration in the global temperature. It has been documented that $\mathrm{CH}_{4}$ is release from municipal solid waste since years and is still released when the landfill is closed (Rajkumar et al., 2010; Kirschke et al., 2013).

Systematic landfill: as study documented by Singh et al. (2018) "India is the largest producer of MSW and landfills are the third largest contributors to the total $\mathrm{CH}_{4}$ emission value of the country". MSW is produced by anthropogenic activities and is one of the main sources for the emission of GHGs especially methane (Du et al., 2017; Singh et al., 2017). Kingsley et al. (2016) reported that the poorly operated landfills are responsible for infectious diseases. Therefore systematic landfill is required which could reduce breeding ground for the vectors, emission of VOCs, metal vapours, harmful gases including GHGs, and inorganic and organic pollutants from leachate. Systematically made landfill converts the $\mathrm{CH}_{4}$ into useful biogas fuel as energy source Matsakas et al. (2017).

\section{Combustion or thermal treatment of Waste:}

In most of the country, it is now in common practice to dump household waste in an open area and burning it. Particulate matter or pollution particle are microscopic solid or liquid matter in the atmosphere released due to unplanned thermal treatment of waste. These particles are harmful to health as carcinogenic particles affect the respiratory system (Dominici et al., 2006; Brunekreef \& Forsberg, 2005; Nemmar et al., 2001). Thermal treatment of waste includes incineration, pyrolysis, gasification and plasma torch (Fam \& Kar, 2016). Systematic methods of thermal treatment for the waste may also produce the energy for fuel and electricity (Gehrmann et al., 2017). A suggestive plan is described in the figure-2.

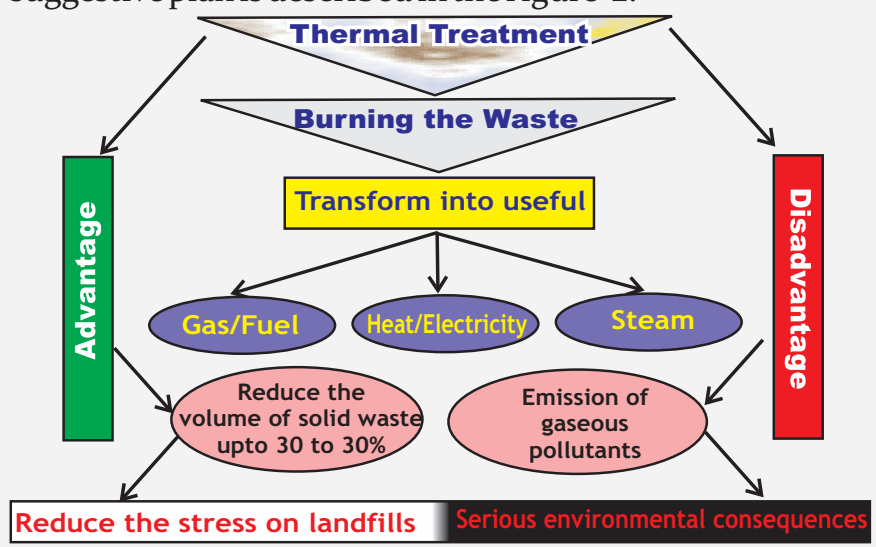

Figure-2: Tentative plan for thermal treatment of Waste

\section{Recycling and recovery of waste:}

Both treatments reduce the emission of greenhouse gases, decreases the load on the landf ill and save the environment (Kumar, 2017). In the scenario of country Brazil, Lino \& Ismail (2013) have stated that selective collection of the things from the trash and recycling it, as an alternative way to promote the social inclusion. Suggestive plan is given in Figure-3\& 4 . 


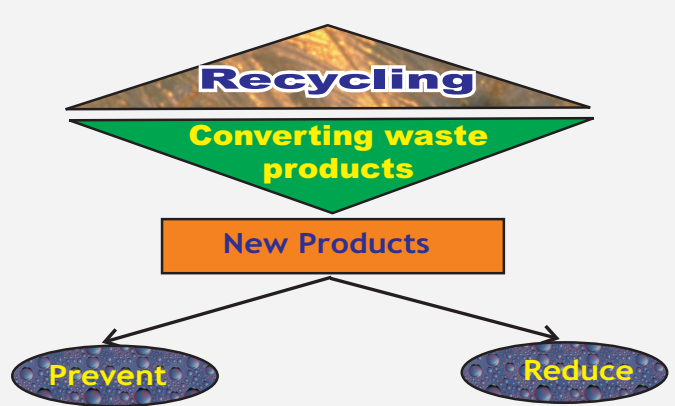

OConsumtion of fresh
raw materials
OEnergy usage

OAir \& Water Pollution

OVolume of landfills

OGreenhouse gas emission

Figure 3: Systematic plan for recycling of waste

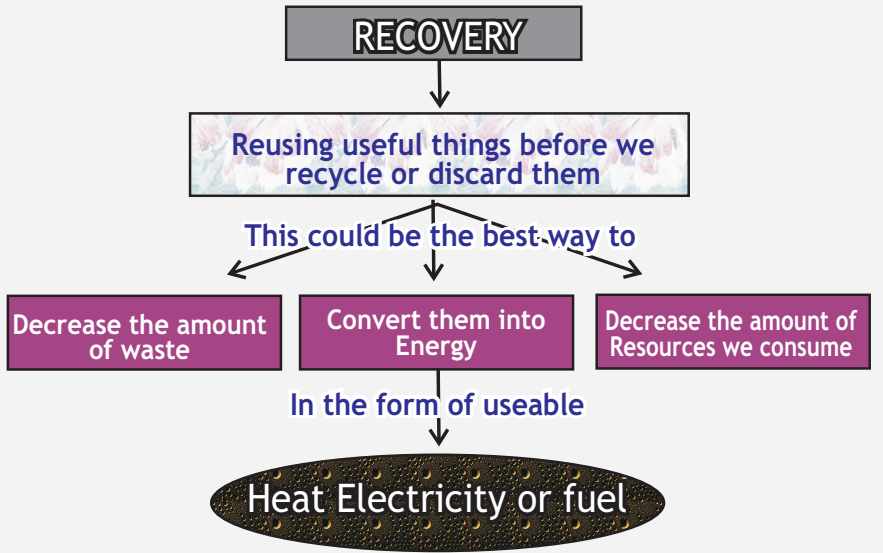

Figure 4: Systematic plan for recovering the Waste

Composting: it is one of the best and cost-effective methods for MSW management. In this method, the organic matter of MSW converts to compost. Vermicomposting is the best example of it (Joshi \& Ahmed, 2017).

\section{Conclusion and future recommendation:} increase in population, urbanization, and industrialization, results in increased in the amount of waste. This is harmful to the environment and as well as for the health of human and animals. Waste management practices were measure in order to discover its link with health problems. It is strongly recommended that one should minimize the waste, be aware of the role of the municipality in the area of public health and give special attention to those workers who are involved in waste management. Finally should create awareness in society about health problems related to toxic waste by interaction and awake them to create the toxic free environment.

\section{References:}

Adelopo, A.O., Haris, P.I., Alo, B., Huddersman, K. \& Jenkins, R.O. (2018): Conversion of solid waste to activated carbon to improve landfill sustainability. Waste Manage. Res., 36(8):708-718.

Alam, P. \& Ahmade, K. (2013): Impact of solid waste on health and the environment. Int. J. Sustain. Dev. Green Econom., V-2, I1:165-168.
Ashworth, D.C., Elliott, P. \& Toledano, M.B. (2014): Waste incineration and adverse birth and neonatal outcomes: A systematic review. Environ. Int., 69:120-132.

Benedetti, M., Fazzo ,L., Buzzoni, C., Comba, P., Magnani, C. \& Fusco, M. (2013): Incidence of soft tissue sarcomas in an Italian area affected by illegal waste dumping sites. Arch. Environ. Occup. Health., 70(3):154-159.

Bourn, M., Robinson, R., Innocenti, F. \& Scheutz. (2018): Regulating landf ills using measured methane emissions: An English perspective. Waste Manag., pii: So956053X(18)30386-6.

Brunekreef, B. \& Forsberg, B. (2005): Epidemiological evidence of effects of coarse airborne particles on health. Eur. Respir. J. 26(2):309-318.

Carpenter, D.O., Ma, J. \& Lessner, L. (2008): Asthma and infectious respiratory disease in relation to residence near hazardous waste sites. Ann. N. Y.Acad. Sci.,1140:201-208.

Danthurebandara, M., van Passel, S. \& van Acker, K. (2015): Environmental and economic assessment of 'open waste dump’ mining in Sri Lanka. Resour. Conserv. Recy., 102:67-79.

Danthurebandara, M., van Passel, S., Nelen, D., Tielemans, Y. \& van Acker, K. (2012): Environmental and socio-economic impacts of landfills. Pub. by: Linnaeus University, Eco-Tech. 40-52.

Daniel, U.I., Duru, C.C., Oriakpono, O. \& Iwuala, M.O.E. (2018): Impacts of Organic Wastes on Plankton Population of Woji Creek, Port Harcourt, Rivers State, Nigeria. Ambient Sci., 05(1):38-42.

De Felice, B., Nappi, C., Zizolf i, B., Guida, M., di Spiezio Sardo, A., Bifulco, G. \& Guida, M. (2012): Telomere shortening in women resident close to waste landf ill sites. Gene, 500(1):101106.

Dehghani, M. \& Vafadar, M. (2017): Qualitative and Quantitative Survey and Suggested Management Strategy of Hospital Solid Waste at Hormozgan Province, Iran. Ambient Sci., o4(1):74-77.

Dhote, J.D. (2016): Review on the diseases caused due to improper handling of Biomedical Waste. Int. Res. J. Sci. Eng., 4(5):98100.

Dominici, F., Peng, R.D., Bell, M.L., Pham, L., Mc Dermott, A., Zeger, S.L. \& Samet, J.M. (2006). Fine Particulate Air Pollution and Hospital Admission for Cardiovascular and Respiratory Diseases. JAMA. 295(10):1127-1134.

Du, M., Peng, C., Wang, X., Chen, H., Wang, M. \& Zhu, Q. (2017): Quantification of methane emissions from municipal solid waste landfills in China during the past decade. Renew. Sustain. Energy Rev., 78: 272-279.

Elliott, P., Briggs, D., Morris, S., de Hoogh, C., Hurt, C., Jensen, T.K., Maitland, I., Richardson, S., Wakefield, J. \& Jarup, L. (2001): Risk of adverse birth outcomes in populations living near landf ill sites. BMJ., 323:363-368.

El-Salam, M.M.A. \& Abu-Zuid, G.I. (2015): Impact of landfill leachate on the groundwater quality: A case study in Egypt. J. Adv. Res., 6(4):579-586.

Fam, L. \& Kar, I. (2016): Recycling and thermal treatment of MSW in a developing country. Resour. Recycl. Waste Manage., 1:1-7.

Fazzo, L., de Santis, M., Mitis, F., Benedetti, M., Martuzzi, M., Comba, P. \& Fusco, M. (2011). Ecological studies of cancer incidence in an area interested by dumping waste sites in Campania (Italy). Ann. Ist. Super Sanita., 47(2):181-191. 
Gehrmann, H.J., Hiebel, M. \& Simon, F.G. (2017): Methods for the Evaluation of Waste Treatment Processes. L. Eng., 2017, Article ID 3567865.

Giusti, L. (2009): A review of waste management practices and their impact on human health. Waste Manage., 29(8):2227-2239.

Gouveia, N. \& Prado, R.R. (2010): Health risks in areas close to urban solid waste landfill sites. Rev. Saude Publica., 44(5):859-66.

Guida, M., de Felice, B., Santafede, D., D’Alessandro, R., di Spiezio Sardo, A., Scognamiglio, M., Ferrara, C., Bifulco, G. \& Nappi, C. (2010): Assessment of DNA damage by RAPD in Paracentrotus lividus embryos exposed to amniotic fluid from residents living close to waste landf ill sites. J. Biomed. Biotechnol., 2010:251767.

Joshi, R. \& Ahmed, S. (2016): Status and challenges of municipal solid waste management in India: A review. Cogent Environ.

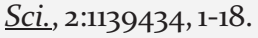

Kah, M., Levy, L. \& Brown, C. (2012): Potential for effects of land contamination on human health. 2. The case of waste disposal sites. L Toxicol Environ Health B Crit Rev., 15(7):44167.

Kirschke, S., Bousquet, P., Ciais, P. \& Zeng, G. et al., (2013): Three decades of Stefanie global methane sources and sinks. Nat. Geosci., 6(10):813-823.

Kingsley, E.N., Paschal, I.O. \& Jude E.O. (2016): Assessment of landfill sites for solid waste management in Delta state, Nigeria.J. Environ. Waste Manage., 3(1):116-122.

Kumar, V. (2017): Recycling of waste and used papers: a useful contribution in conservation of environment: a case study. Asian J. Water Environ. Poll., 14 (4):31-36.

Lavrova, S. \& Koumanova, B. (2010): Landf ill leachate purification in a vertical flow constructed wetland with/without preliminary aerobic treatment. L. Univ. Chem. Tech. Metall., 46(3):299-304.

Lino, F.A.M. \& Ismail, K.A.R. (2013): Contribution of Recycling of Municipal Solid Waste to the Social Inclusion in Brazil. $J$. Waste Manage., 2013:Article ID 429673.

Martuzzi, M., Mitis, F., Bianchi, F., Minichilli, F., Comba, P. \& Fazzo, L. (2009): Cancer mortality and congenital anomalies in a region of Italy with intense environmental pressure due to waste. Occup. Environ. Med., 66(11):725-732.

Mattiello, A., Chiodini, P., Bianco, E., Forgione, N., Flammia, I., Gallo, C., Pizzuti, R. \& Panico, S. (2013): Health effects associated with the disposal of solid waste in landfills and incinerators in populations living in surrounding areas: A systematic review. Int. J. Public Health., 58(5):725-735.

Minichilli, F., Bartolacci, S., Buiatti, E., Pallante, V., Scala, D. \& Bianchi, F. (2005): A study on mortality around six municipal solid waste landfills in Tuscany Region. Epidemiol Prev., 29(5-6 Suppl):53-56.

Moya, D., Aldásb, C., Lópeza, G. \& Kaparajuc, P. (2017): Municipal solid waste as a valuable renewable energy resource: a worldwide opportunity of energy recovery by using waste-t energy technologies. Energy Procedia, 134:286-295.

Musmeci, L., Bellino, M., Cicero, M.R., Falleni, F., Piccardi, A. \& Trinca, S. (2010): The impact measure of solid waste management on health: The hazard index. Ann. Ist Super Sanita., 46(3):293-298.

Myers, S.S. (2009): Global environmental change: the threat to human health (Worldwatch Report 181). Pub. by: World watch Institute, Washington, DC.49p.

Nagarajan, R., Thirumalaisamy, S. \& Lakshumanan, E. (2012): Impact of leachate on groundwater pollution due to nonengineered municipal solid waste landf ill sites of erode city, Tamil Nadu, India. Iranian J. Environ. Health Sci. Eng., 9:35

Namen, A.A., Brasil, Fda C., Abrunhosa J.J., Abrunhosa, G.G., Tarre, R.M. \& Marques F.J. (2014): RFID technology for hazardous waste management and tracking. Waste Manag. Res., 32(9Suppl):59-66.

Naveen, B.P., Mahapatra, D.M., Sitharam, T.G., Sivapullaiah, P.V. \& Ramachandra, T.V. (2016): Physico-chemical and biological characterization of urban municipal landfill leachate. Environ. Poll., 220(A):1-12.

Nemmar, A., Vanbilloen, H., Hoylaerts, M., Hoet, P., Verbruggen, A. \& Nemery, B. (2001): Passage of Intratracheally Instilled Ultrafine Particles from the Lung into the Systemic Circulation in Hamster. Am. J. Respir. Crit. Care Med., 164(9): $1665-1668$.

Patz, J.A., Gibbs, H.K., Foley, J.A., Rogers, J.V. \& Smith, K.R. (2007): Climate Change and Global Health: Quantifying a growing Ethical crisis. EcoHealth, 4(4):397-405.

Porta, D., Milani, S., Lazzarino, A.I., Perucci, C.A. \& Forastiere F. (2009): Systematic review of epidemiological studies on health effects associated with management of solid waste. Environ. Health, 8:60.

Powell, J.T., Townsend, T.G. \& Zimmerman, J.B. (2016). Estimates of solid waste disposal rates and reduction targets for landf ill gas emissions. Nat. Clim. Change, 6(2):162-165.

Rajkumar, N., Subramani, T. \& Elango, L. (2010): Groundwater contamination due to municipal solid waste diposal - a GIS based study in Erode City. Int. J. Environ. Sci., 1(1):39-55.

Rama Murthy, Y., Kapure, G.U., Tripathy, S.K. \& Sahu G.P. (2018): Recycling of ferromanganese gas cleaning plant (GCP) sludge by novel agglomeration. Waste Manag., pii: So956053X(18)30377-5.

Rushton, L. (2003): Health hazards and waste management $\underline{B r}$. Med. Bull., 68(1):183-197.

Russi, M.R., Jonathan, B.B. \& Cullen, M.R. (2008): An examination of cancer epidemiology studies among populations living close to toxic waste sites. Environ. Health, 7:32.

Singh, P. (2013). Impact of Solid Waste on Human Health: A Case Study of Varanasi City. Int. J. of Scient. Eng. Res., 4(11):18401842.

Singh, C.K., Kumar, A. \& Roy S.S. (2017): Estimating Potential Methane Emission from Municipal Solid Waste and a Site Suitability Analysis of Existing Landfills in Delhi, India. Technologies, 5(62):1-16.

Triassi, M., Alfano, R., Illario, M., Nardone, A., Caporale, O. \& Montuori, P. (2015): Environmental Pollution from Illegal Waste Disposal and Health Effects: A Review on the "Triangle of Death". Int. J. Environ. Res. Public Health, 12(2):1216-1236.

Vrijheid, M. (200o): Health effects of residence near hazardous waste landfill sites: A review of epidemiologic literature. Environ. Health Perspect., 108(Suppl 1):101-112.

WHO. (World Health Organization) (2007): Population health and waste management: scientific data and policy options. (Report of a WHO workshop). Pub. by: e World Health Organization, Copenhagen, Denmark. 96 p. 